\title{
HISAB WUJUD AL-HILALL SEBAGAI POLITIK IDENTITAS MUHAMMADIYAH DALAM DISKURSUS HISAB RUKYAT DI INDONESIA
}

\author{
Maskufa \\ Dosen Fakultas Syariah dan Hukum UIN Syarif Hidayatullah Jakarta \\ maskufa@uinjkt.ac.id
}

\begin{abstract}
Muhammadiyah has consistently been using the method of hisab wujûd al-hilâl (the calculation resulted in a matter of time and the position of beginning new moon of Qamariyyah) for about four decades from 1970 to the present time. This steadiness implies that this method turns to be an ideological identity of Muhammadiyah in determining the first day of the fasting month of Ramadhan. Here, this Islamic mass organization believes that a political effort with a particular identity will have a huge impact on making the method of hisab wujûd al-hilâl as a reliable reference to decide ru yah (seeing the new moon when the sun set sat on 29 of the Qamariyah month), and on encouraging majority of Muslim in Indonesia to use it.
\end{abstract}

Keywords: hisab wujûd al-hilâl, Muhammadiyah, politic of identity.

\section{A. Pendahuluan}

Hisab wujûd al-hilâl diindikasikan telah menjadi ideologi di Muhammadiyah sekaligus menjadi politik identitas. Cressida Heyes mendefenisikan politik identitas sebagai aktivitas politik dalam arti luas yang secara teoritik menemukan pengalaman ketidakadilan yang dirasakan oleh kelompok tertentu dalam situasi sosial tertentu pula. Politik identitas lebih mengarah pada gerakan kaum yang termarginalkan dalam kondisi sosial politik dan kultural tertentu dalam masyarakat. ${ }^{1}$ Erick Hieriej menegaskan bahwa politik identitas berkaitan erat dengan upaya memperjuangkan hak-hak dan pengakuan terhadap kelompok-kelompok minoritas, sekaligus penegasan akan adanya keragaman kultural dan hak untuk berbeda dan pengakuan

\footnotetext{
${ }^{1}$ Heyes, Cressida, "Identity Politics", The Stanford Encyclopedia of Philosophy (Fall 2002 Edition), Edward N. Zalta (ed.), URL = http://plato.stanford. edu/archives/ fall2002 /entries/identity-politics/, (diakses 5 Mei 2014).
} 
terhadap perbedaan itu sebagai suatu yang legitimate. ${ }^{2}$ Oleh karena itu, politik identitas dalam studi sosial politik tidak dianggap sebagai ancaman bahkan dianggap sangat penting bagi pluralisme dan demokrasi.

Studi politik identitas sebagai ciptaan social budaya diletakkan oleh Edward Said, Homi Baba dan Gayatri Spivak yang dijuluki sebagai "Holy Trinity of Postcolonial Theories". 3 Postcolonial mengaitkan identitas dengan problema-tika multikulturalisme yang dihadapi kelompok minoritas yang tertindas. Identitas bagi teori ini adalah persoalan memperjuangkan hak untuk menarasikan pengalamannya menjadi korban yang ditimbulkan oleh mekanisme kekuasaan yang menolak dan menekan mereka. Para pemikir Postcolonialis memandang bahwa kondisi dimarginalkan, dikelas duakan, ditekan dan dianggap orang lain dapat menjadi sumber energy dan potensi utama dalam melakukan perubahan. ${ }^{4}$ Donald L. Horowitc dalam Mokhtar Haboddin mendefiniskan politik identitas sebagai pemberian garis yang tegas untuk menentukan siapa yang akan disertakan dan siapa yang akan ditolak. Karena garis-garis penentuan tersebut tampak tidak dapat dirubah, maka status sebagai anggota dan bukan anggota dengan serta merta tampak bersifat permanen. ${ }^{5}$ Hal inilah yang menguatkan asumsi bahwa untuk menegaskan garis yang berbeda dengan mayoritas, Muhammadiyah telah menempatkan dirinya sebagai kelompok "minoritas yang tertekan" dalam diskursus hisab rukyat di Indonesia.

\section{B. Modernisasi Metode Hisab Muhammadiyah.}

Dua slogan yang melekat pada Muhammadiyah sebagai organisasi terbesar Islam modern yaitu jargon "kembali kepada alQur'an dan Hadis" dan jargon "modernis". Bagi Muhammadiyah

${ }^{2}$ Erick Hieriej, "Pluralisme, Politik Identitas dan Krisis Identitas" dalam Ahmad Syafi'I Ma'arif, Politik Identitas dan Masa Depan Pluralisme Kita, (Jakarta: Yayasan Abad Demokrasi, 2012), Edisi Digital, 53-54.

${ }^{3}$ Shrikant B. Sawant, "Postcolonial Theory: Meaning and Significance", Proceedings of National Seminar on Postmodern Literary Theory and Literature , Jan. 27-28, 2012, Nanded, 3.

${ }^{4}$ D. P. Digole, "Postcolonialism: An Aesthetic of Subversion and Reclamation", Proceedings of National Seminar on Postmodern Literary Theory and Literature, Jan. 27-28, 2012, Nanded, 12.

${ }^{5}$ Mokhtar Haboddin, "Menguatnya Politik Identitas di Ranah Lokal", Jurnal Studi Pemerintahan, Vol. 3 Nomor 1 Februari 2012, pdf. 
semua persoalan yang muncul di kalangan umat Islam dapat dicarikan solusinya melalui pemahaman dan penafsiran terhadap sumber utama Al-Qur'an dan Hadis. Pandangan para ulama klasik yang tertuang dalam beberapa buku fatwa adalah produk fatwa dari struktur sosial pada masyarakat muslim klasik dan pertengahan yang tidak tepat lagi digunakan dalam menjawab fenomena yang terjadi saat ini. Sekalipun demikian tidak berarti Muhammadiyah anti mazhab, pendapat mazhab dapat diterima dan digunakan sebagai dasar argumen sepanjang ditemukan juga argumentasinya dalam al-Qur'an dan Sunnah. ${ }^{6}$

Jargon "Kembali kepada al-Qur'an dan Hadis" di Muhammadiyah secara ketat dilakukan dalam bidang akidah dan ibadah, yang dikenal dengan istilah pemurnian. Pemurnian dalam ranah akidah berarti melakukan pengkajian untuk membebaskan akidah dari unsur-unsur khurafat dan tahayul. Adapun pemurnian dalam ranah ibadah maknanya adalah menggali tuntunannya sesuai yang dicontohkan oleh Rasulullah saw tanpa menafikan adanya tannawu' atau variasi dalam kaifiyat ibadah selama ditemukan landasannya dalam sunnah Nabi saw. Varian ibadah yang tidak didukung oleh sunnah bagi Tarjih tidak dapat dipandang sebagai praktek ibadah yang patut untuk diamalkan. ${ }^{7}$

Adapun jargon modernis atau tajdîd dikenakan pada aspek ajaran Islam yang bermuatan muamalah duniawiyah. Tajdîd dalam bidang ini maknanya adalah mendinamisasikan kehidupan masyarakat sesuai capaian ilmu pengetahuan dan kebudayaan yang diraih manusia dengan tetap berada pada semangat dan ruh shar ' $i$. Oleh karena itu, ada beberapa norma yang berubah karena adanya tuntutan untuk berubah. Misalnya di masa lalu dalam menentukan masuknya bulan baru khususnya Ramadan, Syawal dan Zulhijjah digunakan metode rukyat sesuai dengan perintah Nabi dalam hadis-hadisnya, namun dengan berubahnya keadaan umat Islam yang tidak lagi ummiy maka zaman sekarang digunakan metode lain yang lebih akurat dan terukur yakni metode hisab sebagaimana yang dipraktekkan oleh Muhammadiyah saat ini. Model penetapan hukum yang dianut oleh Muhammadiyah ini

\footnotetext{
${ }^{6}$ Nadirsyah Hosen, "Revelation in a Modern Nation State:Muhammadiyah and Islamic Legal Reasoning in Indonesia," Studia Islamika, Indonesian Journal for lslamic Studies Vol. 10, No. 1,2003, 70.

${ }^{7}$ Syamsul Anwar, "Manhaj Tarjih dan Metode Penetapan Hukum dalam Tarjih Muhammadiyah", Makalah disampaikan dalam Pelatihan Kader Tarjih Tingkat Nasional tanggal 26 Januari 2012 di Universitas Muhammadiyah Magelang, 2.
}

INDO-ISLAMIKA, Volume 6 No. 2 Juli-Desember 2016/1437 | 185 
merefleksikan adanya dinamika pemahaman yang berbeda dari pandangan kaum tradisional. Inilah yang menempatkan Muhammadiyah sebagai organisasi reformis. ${ }^{8}$ Semangat tajdîd ini terus digelorakan oleh Muhammadiyah sehingga terpatrikan dalam memori kolektif warga dan simpatisan Muhammadiyah.

Tajdîd atau pengembangan pemikiran Islam dalam menjawab berbagai persoalan kehidupan yang bersifat dinamis, tetap berorientasi pada sumber ajaran. Hal ini dituangkan dalam manhaj tarjih yakni kumpulan prinsip-prinsip dan metode-metode yang melandasi kegiatan tarjih. Tarjih dalam ranah ushul fikih maksudnya adalah melakukan penilaian terhadap suatu dalil shar' $i$ yang secara zahir tampak bertentangan untuk menentukan mana yang lebih kuat. Makna tarjih ini di Muhammadiyah bukan sekedar kuat menguatkan pendapat yang sudah ada, tetapi memuat makna yang lebih luas sehingga hampir mendekati makna ijtihad itu sendiri. Yakni setiap aktifitas intelektual untuk merespon setiap realitas sosial dan kemanusiaan dari sudut pandang agama Islam, khususnya dari sudut pandang norma-norma sharî'ah. ${ }^{9}$

Muhammadiyah menggunakan metode hisab adalah dalam rangka mempertautkan dimensi ideal wahyu dan realita perubahan peradaban manusia. Rukyat bagi Muhammadiyah tidak hanya difahami secara literal parsial, tetapi didialogkan dengan ayat-ayat al-Qur'an yang terkait dengan itu yaitu Q.S. al-Baqarah, 2:185 dan Q.S. Yunus, 10:5 sehingga metodologi yang dikembangkan Muhammadiyah dalam menetapkan awal bulan kamariah sangat elastis produktif. ${ }^{10}$ Awalnya Muhammadiyah menggunakan metode rukyat kemudian sejalan dengan perkembangan ilmu pengetahuan yang didialogkan dengan sumber autentik maka dilakukan perubahan ke metode hisab. Hal ini diperkuat oleh data historis bahwa penggunaan rukyat bukan satu-satunya cara dalam menetapkan awal bulan kamariah seperti yang disinyalir oleh Ibnu Rusyd bahwa hisab sudah mulai digunakan oleh Muthorif bin al-

${ }^{8}$ Nico J. G. Kaptein and Michael Laffan, "Theme Issue: Fatwas in Indonesia Source: Islamic Law and Society", Vol. 12, No. 1, Fatwas in Indonesia (2005), pp. 18 Published by: BRILL Stable URL : http://www.jstor.org/stable/3399289, 4-5.

${ }^{9}$ Syamsul Anwar, "Manhaj Tarjih dan Metode Penetapan Hukum dalam Tarjih Muhammadiyah",Makalah, 1.

${ }^{10}$ Susiknan Azhari, Penggunaan Sistem Hisab dan Rukyat di Indonesia Studi Interaksi Muhammadiyah dan NU, (Jakarta: Balitbang Depag RI, 2007), 81.

186 | INDO-ISLAMIKA, Volume 6 No. 2 Juli-Desember 2016/1437 
Syakhr dari kalangan tabi 'in besar. ${ }^{11}$ Dengan demikian, sebenarnya ijtihad tentang penggunaan hisab oleh Muhammadiyah bukan hal yang baru dalam wacana fikih.

Penggunaan hisab oleh Muhammadiyah selain dilandasi oleh alasan shar i, juga alasan ilmiah dan alasan praktis. Pertama, pengamalan rukyat mengakibatkan sulitnya dibuat sistem penanggalan karena penetapan tanggal satu bulan baru dapat dilakukan pada h-1. Kedua, penggunaan rukyat telah mengakibatkan "masalah" sipil dan agama di kalangan minoritas muslim yang tinggal di wilayah Eropah dan Amerika ketika mereka akan mengajukan cuti hari raya karena belum adanya kepastian hari rayanya kapan. Ketiga, rukyat tidak dapat menyatukan tanggal peringatan hari-hari besar Islam di seluruh dunia. Keempat, rukyat menimbulkan perbedaan pelaksanaan puasa Arafah. ${ }^{12}$ Argumentasi ini dibangun oleh semangat modernisasi dalam tafsir term "rukyat" yang sebenarnya juga tidak tunggal. Muhammadiyah menggunakan metode hisab ini secara konsisten mulai dari tahun 1970 sebagai rekomendasi dari seminar falak hisab Muhammadiyah hingga saat ini. Kontinuitas ini tentunya dibarengi oleh komitmen organisasi Muhammadiyah di setiap lininya.

\section{Politik Identitas Muhammadiyah dalam Diskursus Hisab Rukyat}

Semangat tajdîd yang digelorakan Muhammadiyah dalam penentuan waktu ibadah khususnya awal bulan Ramadan, Syawal dan Zulhijjah telah menjadi komitmen organisasi. Komitmen yang menegaskan sekaligus menegasikan antara kita dan mereka. Inilah yang disebut oleh Donald L Horowitc sebagai politik identitas yakni pemberian garis yang tegas untuk menentukan siapa yang akan disertakan dan siapa yang ditolak. Terlebih garis-garis penentuan itu juga bersifat permanen sehingga status anggota dan bukan anggota menjadi semakin jelas. ${ }^{13}$

Studi tentang politik identitas sebagai ciptaan sosial budaya pasca kolonialisme diletakkan oleh Edward Said, Homi Baba dan Gayatri

${ }^{11}$ Ibn Rushd, Bidāyat al-Mujtahid fî Nihāyat al-Muqtasid, Jilid 1, (Beirut: Dār al-Fikr, tth) Jilid I, 207-208.

${ }^{12}$ Syamsul Anwar, "Zulhijjah, Tahun Baru Hijriah dan Kalender Islam Global, http://www.muhammadiyah.or.id, (diakses 12 Desember 2010).

${ }^{13}$ Mokhtar Haboddin, "Menguatnya Politik Identitas Di Ranah Lokal", Jurnal Studi Pemerintahan, Vol. 3 Nomor 1 Februari 2012, pdf.

INDO-ISLAMIKA, Volume 6 No. 2 Juli-Desember 2016/1437 | 187 
Spivak yang mengaitkan identitas dengan problematika multikulturalisme yang dihadapi oleh kelompok minoritas yang tertindas. Identitas dalam Postcolonial Theory adalah memperjuangkan hak dan menarasikan pengalaman-pengalaman ketidakadilan yang dirasakan kelompok tertentu dari mekanisme kekuasaan yang menolak mereka sehingga mereka merasa termarginalkan. ${ }^{14}$ Selain itu pula sekaligus sebagai penegasan akan adanya keragaman kultural dan hak untuk berbeda yang menuntut adanya pengakuan bahwa perbedaan itu sebagai suatu yang legitimate. ${ }^{15}$ Kondisi termarginalkan, tertindas, dikelasduakan, ditekan dan dianggap orang lain dapat menjadi energi dan kekuatan luar biasa untuk melakukan perubahan dan menegaskan identitasnya.

Kondisi seperti inilah yang "dirasakan" oleh Muhammadiyah kemudian menegaskan identitasnya dalam ranah diskursus hisab rukyat di Indonesia. Sebagai kelompok "minoritas yang tertekan" di tengah menguatnya pandangan mayoritas tentang validitas metode hisab imkân al-ru'yat, maka Muhammadiyah semakin memperkuat argumentasi dan pandangannya tentang lebih validnya metode hisab hakiki wujûd al-hilâl Ideologi hisab wujûd al-hilâl ini diyakini telah menjadi politik identitas yang demikian kuat di Muhammadiyah. "Muhammadiyah memaknai rukyat sebagai ru'yat bî al- 'ilmi, yaitu rukyat dengan ilmu atau ilmu hisab itu sendiri, dan konsisten dalam penggunaannya sampai saat ini," demikian disampaikan oleh Prof. Dr. M. Din Syamsuddin, M.A. dalam sambutan pembukaan Pelatihan Nasional Kader Hisab Muhammadiyah, Jum'at, 5 Oktober 2012. Din menegaskan, jika mau konsisten, mereka yang memaknai rukyat dengan bi al-'aini atau mata telanjang, mestinya tidak boleh memakai alat bantu seperti teropong

${ }^{14}$ Heyes, Cressida, "Identity Politics", The Stanford Encyclopedia of Philosophy (Fall 2002 Edition), Edward N. Zalta (ed.), URL = http://plato. stanford. edu/archives/fall 2002/entries/identity-politics/, diakses tanggal 5 Mei 2014. Bandingkan dengan D. P. Digole, "Postcolonialism :An Aesthetic of Subversion and Reclamation", Proceedings of National Seminar on Postmodern Literary Theory and Literature, Jan. 27-28, 2012, Nanded, 12.

${ }^{15}$ Erick Hieriej, "Pluralisme, Politik Identitas dan Krisis Identitas" dalam Ahmad Syafi'I Ma'arif, Politik Identitas dan Masa Depan Pluralisme Kita, (Jakarta: Yayasan Abad Demokrasi, 2012), Edisi Digital, 53-54. 
dan lain-lainnya."16 Pernyataan Din tersebut semakin menegaskan bahwa hisab sudah menjadi identitas Muhammadiyah.

Berbeda dengan Din, Ulil Abshar mengkritisi penggunaan hisab di Muhammadiyah dengan menyatakan fenomena digunakannya hisab ini agak janggal, sebab, secara logis, mestinya Muhammadiyah mengikuti metode rukyat, karena itulah yang jelas-jelas sesuai dengan makna literal sebuah hadis yang terkenal, "shûmû lî ru'yatihi, wa afthirû li ru'yatihi..". Bukankah selama ini Muhammadiyah dikenal sebagai ormas yang mengumandangkan ide kembali kepada Qur'an dan Sunnah? Masalah rukyat dan hisab memang menjadi bagian dari semacam politik identitas dan karena itu juga merupakan semacam titik selisih antara NU dan Muhammadiyah. ${ }^{17}$ Dengan demikian, sebenarnya wacana bergesernya diskur-sus hisab rukyat yang semula hanya sebagai metode dalam penentuan awal bulan kamariah menjadi ideologi telah menjadikan hisab dan atau rukyat sebagai politik identitas bagi masingmasing ormas, bukan hanya bagi Muhammadiyah.

Penguatan ideologi hisab di satu sisi dan ideologi rukyat di sisi yang lain dalam banyak momen semakin menegaskan bahwa wacana hisab rukyat di Indonesia mengalami lompatan dari sekedar perdebatan argumen normatif ke politik identitas. Hal ini mengakibatkan wajah disparitas antara "kita dan mereka" menjadi semakin jelas. Sebagian tetap berpegang teguh pada teks dengan rukyatnya yang diusung oleh NU. ${ }^{18}$ Rukyat menjadi simbol sekaligus identitas NU dan sebagian

${ }^{16}$ Majelis Tarjih dan Tajdid PP Muhammadiyah Gelar Pelatihan Nasional Kader Hisab Muhammadiyah, http://tarjih.muhammadiyah.or.id. (diakses 14 Maret 2014).

${ }^{17}$ Ulil Abshar Abdalla, NU Ru'yah dan Reformasi Penanggalan, http://islamlib. $\quad$ com $/$ ?site=1\&aid=568\&cat $=$ content $\&$ cid= $=11 \&$ title=nu-ruyah-danreformasi -penanggalan, (diakses 14 Maret 2014).

${ }^{18}$ Pada perkembangannya terkini, metode rukyat yang dikembangkan oleh NU adalah metode rukyat dengan had imkân al-ru'yat yaitu rukyat baru dapat diterima manakala hilal yang memungkinkan secara ilmu pengetahuan dapat dilihat. Ini dapat dilihat dari kasus sidang isbat dalam penentuan 1 Syawal $1432 \mathrm{H}$ walaupun ada dua laporan keberhasilan rukyat di Jepara dan Cakung akan tetapi karena ketinggian hilal dari hisab yang akurat menunjukkan data di bawah angka imkanur rukyat 2 derajat maka laporan keberhasilan rukyat itu tidak diterima, sehingga dalam mazhab ru'yat bi al-fi 'li sendiri terdapat perbedaan. Pertama mazhab ru'yat bi al-fi'li yang dibatasi oleh imkanur rukyat (had imkân al-ru'yat) dan mazhab ru'yat bi al-fi'li yang tidak mengenal batas imkanur rukyat. Lihat Maskufa dan Wahyu Widiana, Titik Kritis Dalam Penentuan Puasa dan Hari Raya di Indonesia dalam Ahkam Jurnal Ilmu Syariah Vol XII No.1 Januari 2012, 73. 
yang lain berpegang pada jiwa teks dengan hisabnya yang diusung oleh Muhammadiyah. Hisab menjadi simbol dan identitas Muhammadiyah. Hisab dan rukyat bagi kedua ormas Islam ini seakan menjadi trade mark- nya dalam memahami teks keagamaan yang berkaitan dengan metode penentuan puasa dan hari raya.

Perbedaan antara hisab dan rukyat pada akhirnya menjadi sumber konflik di kalangan Muhammadiyah dan Nahdlatul Ulama, ketegangan di lembaga keluarga, masyarakat bahkan dengan pemerintah. Pemerintah berupaya untuk menengahi kedua ideologi ini dengan membuat formula rukyat yang bersendikan hisab atau dikenal dengan hisab imkân al-ru'yat ternyata belum dapat diterima secara utuh dan legowo oleh keduanya. Bahkan alih-alih menjadi penengah, Pemerintah yang diwakili oleh Menteri Agama yang berasal dari ormas itu dalam mengumumkan hasil sidang isbat ternyata diindikasikan mempunyai kecenderung-an pendapat yang sesuai dengan afiliasi ormasnya. Sebagai salah satu produk hukum Keputusan Menteri Agama (KMA) terkait dengan penetapan puasa dan hari raya yang dikeluarkan setelah proses sidang isbat tidak bebas dari subjektifitas dan pemihakan.

Pemerintah terkadang dianggap bersikap sangat otoriter oleh Muhammadiyah dan terlalu memihak NU karena adanya larangan bertakbiran keliling kota karena esoknya menurut versi rukyat masih Ramadan. Juga adanya pelarangan penggunaan fasilitas umum untuk salat id pada hari pemerintah belum memutuskan. Putusan sidang isbat yang didominasi oleh rukyat semakin membuat Muhammadiyah teralienasi. Keberhasilan rukyat dalam beberapa kasus yang hasilnya sama dengan hisabnya Muhammadiyah tidak diterima oleh peserta sidang isbat yang mayoritas menggunakan metode rukyat dan hisab imkân al-ru'yat. Hal ini sesuai dengan pendapat Moh.Mahfudh MD bahwa hukum merupakan produk politik sehingga karakter setiap produk hukum akan sangat ditentukan atau diwarnai oleh imbangan kekuatan atau konfigurasi politik yang melahirkannya. ${ }^{19}$ Kondisi sidang

${ }^{19}$ Moh. Mahfud MD, Pergulatan Politik dan Hukum di Indonesia, (Yogyakarta: Gama Media, 1999), 4. Pandangan Mahfudz MD ini sebenarnya sejalan dengan Daniel S. Lev bahwa tempat hukum di dalam negara tergantung pada keseimbangan politik, defenisi kekuasaan, evolusi ideologi politik, ekonomi, sosial dan seterusnya. Bedanya bila Mahfudh MD menggunakan bingkai konfigurasi rezim politik secara periodik sedangkan Lev lebih bersifat tematik pada kasus-kasus 
isbat dari unsur kepesertaan sebagaimana dideskripsikan oleh Ki Ageng AF. Wibisono adalah peserta sidang isbat baik yang mewakili Pemerintah, organisasi ulama, dan semua yang memegang kekuasaan dalam prosesi sidang isbat tersebut adalah individu dari golongan yang sama. Sehingga keputusan sidang lebih cenderung membela pihak mayoritas dengan lebih mendengar, membela, dan memenangkan mereka. Padahal ada pihak lain yang mestinya juga didengar pendapatnya dan dihormati akan tetapi argumen dan dalil dari pihak di luar mereka ini ditolak bahkan cenderung memaksa untuk menjalankan keputusannya. ${ }^{20}$

Kasus-kasus penetapan 1 Syawal berikut menambah kuat kesan adanya hegemoni kelompok dan politisasi agama oleh Pemerintah. Penetapan 1 Syawal 1418H/1998M, Pemerintah menolak laporan keberhasilan rukyat oleh 3 orang di Cakung dan 3 orang di Pantai Prapat Tunggal Bawean karena laporan tersebut diragukan sebab hilal masih di bawah batas minimal imkân al-ru'yat. Laporan yang demikian dianggap sebagai laporan yang tidak kuat. ${ }^{21}$

Sidang isbat Penetapan 1 Syawal $1427 \mathrm{H} / 2006 \mathrm{M}$ juga menolak klaim rukyat Cakung dan Bangkalan sehingga Muhammadiyah dan NU wilayah Jawa Timur berlebaran 1 hari sebelum penetapan Pemerintah. Keputusan sidang isbat dalam Penetapan 1 Syawal 1428H / 2007M menolak klaim rukyat Cakung. Demikian juga penetapan 1 Syawal $1432 \mathrm{H} / 2011 \mathrm{M}$ menolak klaim rukyat tim Kemenag Pantai Kartini Jepara dan Cakung juga ditolak, ${ }^{22}$ sehingga Muhammadiyah, Dewan Dakwah Islamiyah Indonesia (DDII), Jama'ah Anshorut Tauhid, Front Pembela Islam (FPI), Majelis Mujahidin Indonesia (MMI), Jum'iyat An-Najat, Hizbut Tahrir Indonesia (HTI), Pondok Pesantren Modern Gontor, dan sebagian warga NU yang mengakui laporan rukyat

tertentu. Lihat Daniel S. Lev, Hukum dan Politik di Indonesia Kesinambungan dan Perubahan, (Jakarta: LP3ES, 2013), cet. ke-3, xv dan xxi.

${ }^{20} \mathrm{Ki}$ Ageng AF. Wibisono,"Ulil Amri di Indonesia," Khazanah, Suara Muhammadiyah 18 / 97 I 29 Syawal - 14 Zulhijjah 1433H / 16-30 September 2012. 23-24.

${ }^{21}$ Departemen Agama, Himpunan Keputusan Menteri Agama tentang Penetapan Tanggal 1 Ramadan dan 1 Syawal Tahun 1381-1418 H/1962-1997M, 361

${ }^{22}$ Mutoha Arkanuddin, "20 Tahun Keputusan Sidang Itsbat Penentuan Awal Bulan Ramadan, Syawal dan Dzulhijjah di Indonesia”, http://rukyatulhilal.org/ artikel /20-tahun-isbat-indonesia.html, (diakses 12 Mei 2014). 
(PWNU DKI ${ }^{23}$ berlebaran mendahului penetapan Pemerintah. Lihat tabel perbedaan hari raya idul fitri berikut:

Tabel 1,

Penetapan Idul Fitri di Indonesia

Tahun 1418 H/1998 M - 1432 H/2011 M

\begin{tabular}{|c|c|c|c|c|}
\hline No & $\begin{array}{c}\text { Syawal } \\
\text { Tahun }\end{array}$ & $\begin{array}{l}\text { Tinggi } \\
\text { Hilal }\end{array}$ & $\begin{array}{c}\text { Laporan } \\
\text { Rukyat }\end{array}$ & Idul Fitri \\
\hline 1 & $\begin{array}{l}1418 \mathrm{H} \\
/ 1998 \mathrm{M}\end{array}$ & $0^{\circ} 18^{\prime}$ & $\begin{array}{c}\text { Klaim rukyat } \\
\text { Cakung dan } \\
\text { Bawean ditolak }\end{array}$ & 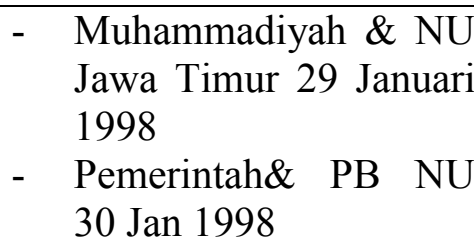 \\
\hline 2 & $\begin{array}{l}1423 \mathrm{H} / \\
2002 \mathrm{M}\end{array}$ & $0^{\circ} 31^{\prime}$ & - & $\begin{array}{ll}\text { - } & \text { Muhammadiyah } 5 \text { Des } \\
& 2002 \\
\text { - Pemerintah/NU } 6 \text { Des } \\
\\
2002\end{array}$ \\
\hline 3 & $\begin{array}{l}1427 \mathrm{H} / \\
2006 \mathrm{M}\end{array}$ & $0^{\circ} 31^{\prime}$ & $\begin{array}{l}\text { Klaim Rukyat } \\
\text { Cakung dan } \\
\text { Bangkalan } \\
\text { ditolak }\end{array}$ & $\begin{array}{ll}\text { - } & \text { Muhammadiyah } \\
& \text { Oktober } 2006 \\
\text { - } & \text { Pemerintah/NU } \\
& \text { Oktober } 2006 \\
\end{array}$ \\
\hline 4 & $\begin{array}{l}1428 \mathrm{H} / \\
2007 \mathrm{M}\end{array}$ & $0^{\circ} 22^{\prime}$ & $\begin{array}{l}\text { Klaim rukyat } \\
\text { Cakung ditolak }\end{array}$ & $\begin{array}{ll}- & \text { Muhammadiyah } \\
& \text { Oktober } 2007 \\
- & \text { Pemerintahh/NU } \\
& \text { Oktober } 2007 \\
\end{array}$ \\
\hline 5 & $\begin{array}{l}1432 \mathrm{H} / \\
2011 \mathrm{M}\end{array}$ & $0^{\circ} 22^{\prime}$ & $\begin{array}{l}\text { Klaim rukyat } \\
\text { Cakung dan } \\
\text { Pantai Kartini } \\
\text { Jepara ditolak }\end{array}$ & $\begin{array}{ll}- & \text { Muhammadiyah } \\
& \text { Agustus 2011 } \\
- & \text { Pemerintah/NU } \\
& \text { 31Agustus 2011 }\end{array}$ \\
\hline
\end{tabular}

Dari tabel 1, di atas dapat dilihat bahwa selama era reformasi dari tahun 1998 sd 2011, dalam rentang 14 tahun hanya ada 5 perbedaan hari raya Idul Fitri antara Muhammadiyah dan Pemerintah. Perbedaan hari raya diprediksikan akan terjadi lagi pada tahun 2023M

${ }^{23}$ Robby Abror, "Mengkritisi Politisasi Penetapan 1 Syawal 1432 H”, Suara Muhammadiyah No.19 Edisi 1-15 Oktober 2011. 
mendatang. ${ }^{24}$ Ini menunjukkan stigma bahwa Muhammadiyah selalu berbeda dengan Pemerintah menjadi terbantahkan. Perbedaan antara hisab dan rukyat terjadi setelah Pemerintah memutuskan untuk menggunakan kriteria imkân al-ru'yat yang disepakati oleh MABIMS. Pembatasan inilah yang sebenarnya menyebabkan adanya perbedaan penetapan puasa dan hari raya antara Muhammadiyah, NU, dan Pemerintah.

Klaim rukyat dalam beberapa kasus tersebut sudah sesuai dengan argumen normatif penganut ru'yat al-hilâl bi al-fi 'li maka sudah semestinya klaim itu diterima. Akan tetapi, karena dianggap tidak memenuhi unsur hisab imkân al-ru'yatnya Pemerintah sesuai kesepakatan MABIMS, klaim rukyat tersebut ditolak. MUI bahkan menyatakan: "Jika mustahil, tapi ada yang mengaku melihat harus ditolak". ${ }^{25}$ Dasar dari rujukan MUI ini adalah fatwa MUI Nomor 2/2004 tentang Penetapan Awal Ramadan, Syawal, dan Zulhijjah, padahal kalau dicermati isi fatwa itu tidak ada penyebutan tentang berapa ketinggian hilal itu mungkin atau mustahil dapat dirukyat. ${ }^{26}$ Keberhasilan tim rukyat yang disebar oleh Kementerian Agama dalam beberapa kasus di atas didukung oleh data posisi hilal yang sudah di atas ufuk, maka seyogyanya laporan itu diterima sebagai suatu kebenaran. Adanya pembatasan imkân al-ru'yat itu menjadi sebab adanya perbedaan penetapan puasa dan hari raya. Dengan demikian, Pemerintah sebenarnya yang berkontribusi secara signifikan membuat wacana hisab rukyat belum dapat terselesaikan hingga saat ini.

Penentuan 1 Syawal menjadi wacana yang seksi karena menjadi pertaruhan kredibilitas Pemerintah dan ormas-ormas Islam pendukung yang sebenarnya jauh hari sudah menetapkan tanggal 1 Syawal dalam kalender mereka. Kalender yang ditetapkan berdasarkan hisab itu menjadi acuan bagi Pemerintah untuk menetapkan hari libur dan cuti bersama hari raya Idul Fitri, dan bagi masyarakat muslim untuk merencanakan agenda mudik. Mudik bukan persoalan sederhana,

\footnotetext{
${ }^{24}$ Lihat tabel prediksi hisab tentang penetapan hari raya Idul Fitri dari tahun 2012M/1433H sd 2025M/1446H dalam Maskufa dan Wahyu Widiana, Titik Kritis Penentuan Awal Puasa dan Hari Raya di Indonesia, Jurnal, AHKAM/ Vol.XII/No.1/Januari 2012/ISSN:1412-4734, 78.

${ }^{25}$ Asrori S. Karni, Jalan Stagnan Titik Temu Lebaran, http://arsip. gatra.com /2011-09-06/majalah /artikel.php?pil=23\&id=150107, akses tanggal 22 Mei 2015.

${ }^{26}$ Lihat Sekretariat MUI, Himpunan Fatwa MUI Sejak 1975 Edisi Terbaru, (Jakarta: Erlangga, 2015), 211-214.
} 
banyak aspek yang terkait dengan "mudik" ini. Misalnya pihak pengampu kebijakan transportasi masal seperti kereta api, kapal laut dan pesawat terbang sudah membuka layanan mudik tiga bulan sebelum hari H. Demikian pula perbaikan jalur transportasi darat, persiapan stok kebutuhan pokok (pangan), sandang dan lainnya semuanya mempunyai keterkaitan dengan "mudik". Persiapanpersiapan yang dilakukan oleh berbagai pihak ini semuanya mengacu pada kalender yang sudah ditetapkan oleh Pemerintah. Alangkah naifnya apabila hari raya idul fitri yang sudah ditetapkan dalam kalender itu kemudian dianulir sendiri oleh Pemerintah. Oleh karena itu, wacana penetapan hari raya idul fitri khususnya bukan lagi sebatas wacana normatif. Argumentasi masing-masing pihak lebih dipengaruhi oleh semangat pertaruhan kredibilitas dan politik identitas sehingga kesan memaksakan kehendak sangat kental terasa.

Penafian hasil rukyat oleh penganut rukyat sendiri seperti NU, alWasliyah, dan Mathla'ul Anwar menjadi menarik untuk dikritisi. Terlepas dari adanya pergeseran paradigma rukyat oleh mereka, tetapi sebagai penganut Ahli Sunnah wal Jama'ah yang sangat kukuh berpegang pada teks hadis Nabi saw tentang ru'yat bi al-fi 'li sudah semestinya laporan keberhasilan rukyat itu menjadi kabar baik untuk ditetapkannya hari raya idul fitri dengan rukyat yang berhasil bukan dengan hisab. ${ }^{27}$ Inilah yang dikritisi oleh KH. Salahuddin Wahid tentang lambatnya pengumuman penentuan 1 Syawal $1432 \mathrm{H}$ yakni sekitar pukul 20.30 WIB, yang berarti pukul 22.30 di Papua. Menurutnya, kalau para ahli astronomi dan para ulama yakin bahwa hilal tidak mungkin terlihat pada 29/8, tanpa menunggu hasil ikhtiar melihat hilal pun, sudah bisa diumumkan bahwa 1 Syawal jatuh pada Rabu (31/8). Ia meminta pemerintah melalui ahli astronomi untuk mengkonfirmasi jika ada pihak-pihak yang memang telah melihat hilal agar diakui kesaksiannya sebagai kebenaran dan menyarankan untuk mengkaji pertimbangan tentang mengapa pihak Malaysia, Brunei,

${ }^{27}$ Padahal hasil Munas Alim Ulama NU di Situbondo (1983 M) dan Cilacap (1987) serta rekomendasi Seminar Penyerasian Metode Hisab dan Rukyat (1994M) menegaskan bahwa ditetapkannya awal Ramadan dan awal Syawal hanya dengan rukyat atau menggenapkan bilangan bulan 30 hari, apabila pengumuman Pemerintah hanya didasarkan pada hisab semata maka warga NU tidak wajib mengikuti dan mentaatinya, jelas dalam keputusan itu tidak menyebukan batas ketinggian hilal. Lihat Aziz Masyhuri, Masalah Keagamaan hasil Muktamar dan Munas Ulama NU ke satu 1926 s/d kedua puluh sembilan 1994, 300-301 dan 325-327. Lihat juga Lajnah Falakiyah PB NU, Pedoman Rukyat dan Hisab Nahdlatul Ulama, 12-19. 
Singapura dan negara-negara di Timur Tengah dan Eropa yang memutuskan 1 Syawal sama dengan Muhammadiyah yakni pada Selasa $(30 / 8){ }^{28}$

Pergeseran paradigma rukyat ke arah hisab yakni dari ghair had imkân al-ru'yat ke arah had imkân al-ru'yat ${ }^{29}$ telah membuat mazhab ru'yat al-hilâl bi al-fi'li tidak lagi satu kata dalam menyikapi hasil sidang isbat. Hal ini dapat dilihat dalam kasus penetapan hari raya Idul Fitri bagi kalangan Nahdliyin, pada Idul Fitri tahun 2006 PW NU Jawa Timur berlebaran 1 hari sebelum keputusan PB NU dan Pemerintah. Demikian juga dengan kasus Idul Fitri tahun 2011 PW NU DKI Jakarta memutuskan untuk berlebaran mendahului PB NU dan Pemerintah serta berbarengan dengan Muhammadiyah. Kedua kasus ini menunjukkan bahwa di internal mazhab ru'yat al-hilâl bi al-fi 'li pun terjadi perbedaan pendapat dalam menyikapi keberhasilan rukyat, padahal keberhasilan rukyat menjadi poin penting dalam menentukan puasa dan hari raya. Menurut Agus Purwanto, inilah salah satu keberhasilan Prof. Thomas dalam meyakinkan dan merobah cara berfikir orang-orang Kemenag dan NU dari rukyat ke hisab imkân alru'yat. Namun belum berhasil "merayu" orang Muhammadiyah untuk merubah kriteria wujûd al-hilâl menjadi imkân al-ru'yat. Secara manusiawi, sepertinya beliau gemes juga ${ }^{30}$ Pene-tapan idul fitri sepertinya menjadi lahan kontestasi ruang publik yang memperhadaphadapkan antara Muhammadiyah dengan negara sebagai rezim politik

\footnotetext{
${ }^{28}$ Robby Abror, "Mengkritisi Politisasi Penetapan 1 Syawal 1432 H”, Suara Muhammadiyah No.19 Edisi 1-15 Oktober 2011, 57.

${ }^{29}$ Perubahan metode rukyat pada had imkanur rukyat ini sebagaimana dikemukakan oleh KH. Ahmad Ghazali Masruri Ketua Lajnah Falakiyah PB NU, Lihat Maskufa, Antara Hisab dan Rukyat (Studi Normatif terhadap Penentuan Awal Bulan Qamariyah), Laporan Penelitian, (Jakarta: Lembaga Penelitian UIN Syarif Hidayatullah Jakarta, 2004), 61. Lihat juga PB al-Wasliyah menganut faham rukyatulhilal bil fi'li dengan mempertimbangkan had imkanur rukyat 2 derajat dengan tetap menunggu pengumuman Pemerintah. Lihat "al-Wasliyah Prediksikan 15 Oktober Idul Adha," http://www.medan bisnis-daily.com/m/news/ (akses 12 September 2014). Jamiyah Mathlaul Anwar menganut faham rukyat hilal bil fi'li dengan kriteria imkanur rukyat 2 derajat. Lihat "Ini Pandangan Perwakilan Ormas dalam Sidang Itsbat," http://www.kemenag.go.id/index.php?a...id... (diakses 12 September 2014).

${ }^{30}$ Agus Purwanto, "Sidang Itsbat sudah tidak Relevan", Dialog dalam Suara Muhammadiyah No.19/TH.KE-96 1-5 Oktober 2011, 29.
} 
kekuasaan dan ormas Islam yang entah dengan dalih apa sehingga berpura-pura berada di belakang Negara. ${ }^{31}$

Politisasi agama dalam penentuan idul fitri tahun 2011 sangat kentara. Hal ini dapat dilihat dari adanya pergeseran semangat musyawarah yang menjunjung nilai-nilai tasamuh kepada upaya memojokkan ormas yang berbeda dengan Pemerintah dan suara mayoritas. Politik identitas hisab imkân al-ru'yat sedang menemukan panggungnya dalam sidang isbat tahun $1432 \mathrm{H} / 2011 \mathrm{M}$ yang dilangsungkan secara live. Adanya pemaksaan kehendak dan menyalahkan pihak-pihak yang mengaku telah melihat hilal serta meminta kepada Muhammadiyah untuk merubah metode hisabnya karena dianggap sudah usang yang dikemukakan dalam sidang isbat itu tidak hanya menyakiti warga Muhammadiyah, tetapi juga umat Islam lain yang berlebaran berbeda dengan Pemerintah. Apalagi faktanya hampir 50 negara $^{32}$ berlebaran pada hari yang sama dengan Muhammadiyah. Argumen yang dikemukakan oleh MUI dan Kemenag dalam menolak klaim rukyat pada tahun 2011 itu adalah posisi hilal mustahil dapat dirukyat karena posisinya berada di bawah kesepakatan MABIMS. Kalau 2 derajat ini merupakan keputusan MABIMS sudah semestinya seluruh negara MABIMS berlebaran pada hari yang sama dengan yang ditetapkan oleh Kemenag yaitu hari Rabu. Ternyata hanya Indonesia yang menetapkan idul fitri hari Rabu tanggal 31 Agustus 2011.

Konsistensi Kemenag dalam mengusung hisab imkân al-ru'yat 2 derajat dan penolakan terhadap klaim rukyat apabila mustahil hilal dapat dilihat sebenarnya dapat menjadi acuan Kemenag untuk mengambil kebijakan strategis akan perlu tidaknya melakukan sidang isbat dan menyebar tim pemantau hilal di lebih dari 60 titik di seluruh Indonesia. Karena semua prosesi itu memerlukan biaya sangat tinggi, padahal hasilnya sudah dipaksakan pada tanggal tertentu. Ketidakkonsistenan Kemenag inilah menurut Andy Dermawan ${ }^{33}$ sebenarnya yang telah menyumbang ketidakharmonisan dan kekacauan di negeri ini, bukan NU atau Muhammadiyah. Negara dengan sengaja "merusak"

${ }^{31}$ Zuly Qodir, "Rezim Politik Idul Fitri," Suara Muhammadiyah No.19/96 Edisi 1-15 Oktober 2011, 22-23.

${ }^{32}$ Robby Abror, "Mengkritisi Politisasi Penetapan 1 Syawal 1432 H", Suara Muhammadiyah No.19/96 Edisi 1-15 Oktober 2011, 57.

${ }^{33}$ Isma, "Basa Basi Sidang Itsbat", dalam Suara Muhammadiyah No. 19/96 Edisi 1-15 Oktober 2011, 10 
ukhuwah islamiyah yang sudah terjalin dengan baik selama ini dengan berpura-pura memihak pada salah satu kelompok. Menteri Agama tidak dapat mengambil perannya secara netral dan independen.

Perbedaan penetapan 1 Syawal sebenarnya sudah biasa terjadi, tetapi maknanya menjadi lain manakala Pemerintah terlalu memaksakan kehendaknya. Ada kesan Pemerintah memaksakan keputusannya dengan mendeskreditkan kepu-tusan yang diambil oleh kelompok atau ormas yang berbeda dengan Pemerintah. Penayangan sidang isbat pada 29 Agustus 2011 secara live itu sebenarnya menjadi momen penting untuk evaluasi total karena publik luas tahu sidang para ulama tersebut ternyata tidak ubahnya seperti sidang partai politik, kasar dan naif serta tidak merepresentasikan keutamaan dan kewibawaan ulama. ${ }^{34}$

Inilah yang menyebabkan Keputusan Pemerintah RI melalui Menteri Agama, Suryadharma Ali, disinyalir telah terjebak pada aroma politisasi agama. Pemerintah terlalu dalam ikut campur dalam wilayah keagamaan. Menurut Din Syamsuddin, Ketua Umum PP Muhammadiyah, Pemerintah RI telah bersikap inkonstitusional karena telah melanggar UUD 1945 Pasal 29. Sidang Isbat hanya memberi kesempatan dan menjustifikasi kepentingan Pemerintah, ada laporan sudah melihat hilal tetapi ditolak. Pendapat tersebut dilontarkan Din (30/8) yang menilai bahwa Pemerintah lebih memihak pada suatu ormas Islam tertentu dan menafikan ormas Islam lain yang berbeda. ${ }^{35}$ Dalam kesempatan lain ketika penentuan awal puasa yang digunakan PP Muhammadiyah dianggap oleh Nasaruddin Umar (wakil Menteri Agama saat itu) agak berbeda dengan ajaran dunia Islam. Din juga menegaskan bahwa: banyak dalil dari al-Qur'an dan Hadis yang menyuruh kita untuk mencermati peredaran bumi, bulan, dan matahari. Inilah yang digunakan oleh Muhammadiyah, selain itu warga negara punya kebebasan menunaikan agama dengan ibadahnya itu yang harus dihargai oleh pejabat tinggi kementerian agama, jangan bersikap inkonstitusional, karena itu bisa dianggap inkonstitusional karena tidak menghargai pandangan orang lain. ${ }^{36}$

\footnotetext{
${ }^{34}$ Agus Purwanto, “Sidang Itsbat Sudah Tidak Relevan”, 30.

${ }^{35}$ Robby Abror, "Mengkritisi Politisasi Penetapan 1 Syawal 1432 H," 56.

${ }^{36}$ Al-Amin, "Disebut Berbeda dari Ajaran Islam Muhammadiyah Kecam Wamenag," http://www.merdeka.com/peristiwa/disebut-berbeda-dari-ajaran-islammuham-madiyah-kecam-wamenag.html, (diakses tanggal 25 Juni 2014).
} 
Sejalan dengan semakin canggihnya perkembangan ilmu pengetahuan di bidang astronomi, maka penetapan kapan hari raya dapat dihitung jauh hari sebelumnya sehingga peluang ada tidaknya perbedaan semestinya sudah dapat diantisipasi oleh Pemerintah dan ormas Islam. Inilah yang dilakukan oleh Pemerintah pada penetapan hari raya tahun 2002. Pemerintah memberikan arahan yang menyejukkan, Menteri Agama Said Agil Husin Al-Munawar mengatakan, meski umat Islam hampir dipastikan akan mengalami perbedaan tentang saat Idul Fitri, hal tersebut bukan masalah dan justru merupakan kekayaan khazanah umat Islam. "Umat Islam sudah terbiasa dengan perbedaan dan harus saling memahami, bukan menjadikan perbedaan itu ke arah perpecahan, tetap saling menghormati dan tetap dalam kebersamaan," Muhammadiyah mengumumkan awal Syawal pada 5 Desember 2002, bukan untuk seluruh masyarakat tetapi atas nama organisasi tersebut. ${ }^{37}$ Din Syamsuddin menegaskan bahwa perbedaan penetapan 1 Syawal antara Muhammadiyah dan Pemerintah murni masalah keagamaan dan pemahaman Islam dari Muhammadiyah tidak ada motif politis di balik perbedaan penetapan itu. ${ }^{38}$

Bila pada saat ini, Pemerintah dianggap oleh Muhammadiyah sangat memihak pada NU maka beberapa tahun sebelumnya pemerintah juga dianggap oleh NU sangat memihak Muhammadiyah manakala penetapan idul fitrinya bersamaan dengan Pemerintah dan dilakukan berdasarkan hisab. Keadaan ini sangat terasa manakala Menteri Agamanya Munawir Sjadzali selama dua periode. Pada masa ini keputusan-keputusan sidang isbat didominasi oleh hisab. Misalnya penetapan Ramadan tahun $1984 \mathrm{M} / 1404 \mathrm{H},{ }^{39}$ tahun $1987 \mathrm{M} / 1407 \mathrm{H},{ }^{40}$

\footnotetext{
${ }^{37}$ Suara Merdeka, Muhammadiyah: Idul Fitri 5 Desember Kamis, edisi 28 November 2002.

${ }^{38}$ Priyambodo RH, PBNU-Muhammadiyah: Kedepankan Toleransi Jika Ada Perbedaan Idul Fitri, dari http://www.antaranews.com/berita/78371/pbnumuhammadiyah-kedepankan-toleransi-jika-ada-perbedaan-idul-fitri, (diakses tanggal 7 Januari 2016).

${ }^{39}$ Pada tahun ini KMA Nomor: 40 Tahun 1984 memutuskan bahwa tanggal 1 Ramadhan jatuh hari Jum'at tanggal 1 Juni 1984 dengan dasar pertimbangan bahwa seluruh ahli hisab dan rukyat yang tergabuing dalam badan hisab dan rukyat Depag sepakat tanggal 1 Ramadhan 1404 jatuh pada tanggal 1 Juni 1984 berdasarkan istikmal, Lihat Depag, Himpunan Keputusan Menteri Agama Tentang Penetapan Tanggal 1 Ramadhan dan 1 Syawal Tahun 1831-1418H/1962-1997 M, (Jakarta: Depag, 2000),161.
} 
tahun $1989 \mathrm{M} / 1409 \mathrm{H}^{41}$ dan tahun $1990 \mathrm{M} / 1410 \mathrm{H}^{42}$ Menanggapi rumusan Keputusan Menteri Agama yang didominasi oleh hisab ini maka NU membuat Rumusan hasil Munas Alim Ulama NU di Pesantren Ihya Ulumuddin Kesugihan Cilacap pada tanggal $23-26$ Rabiulawal 1408 H/15-18 November 1987 “jika pengumuman (pengumuman Depag tentang awal Ramadan dan Syawal) hanya semata-mata berdasarkan hisab maka warga NU tidak wajib mengikutinya". ${ }^{43}$ NU pada beberapa kasus di atas memilih tafaruq atau berselisih pendapat dengan Pemerintah.

Tafaruq yang dilakukan oleh NU itu dikarenakan penetapan yang dilakukan oleh Pemerintah lebih didominasi oleh hisab. Tentunya ini bertentangan dengan Keputusan Munas Alim Ulama NU 13-16 Rabiul Awal 1404 H/18-21 Desember 1983 M di Situbondo yang kemudian dikukuhkan oleh Muktamar NU ke-27 tahun 1984, dan Munas Alim Ulama NU di Cilacap tahun 1987 bahwa dalam penetapan Ramadan, Syawal, dan Zulhijjah, wajib didasarkan atas Rukyatulhilal bi al-Fi 'li atau Istikmâl. Sedangkan kedudukan hisab hanyalah sebagai pembantu dalam melakukan Rukyat. ${ }^{44}$ Rukyat lebih diutamakan oleh NU karena rukyat atau pengamatan hilal yang digunakan untuk menentukan waktu

${ }^{40}$ Tanggal 1 Ramadhan 1407 jatuh pada hari Rabu tanggal 29 April 1987 dengan dasar bahwa pada tanggal 29 Syakban 1407H / 28 April 1987 hilal di seluruh wilayah Indonesia masih di atas ufuk sekitar $1^{\circ} 16^{\prime} \mathrm{s} / \mathrm{d} 3^{\circ}$ oleh karenanya baik hilal dapat dilihat ataupun tidak seluruh ahli hisab dan rukyat yang tergabung dalam Badan Hisab Rukyat Depag sepakat bahwa 1 Ramadhan 1407 jatuh pada hari rabu tanggal 29 April 1987. Depag, Himpunan Keputusan Menteri Agama, 169-172

${ }^{41}$ Bahwa berdasarkan hasil hisab posisi hilal pada akhir Syakban $1409 \mathrm{H} /$ Kamis tanggal 6 April 1989 ada pada posisi 0 sd 2 40' di seluruh wilayah Indonesia maka baik hilal dapat dilihat ataupun tidak, 1 Ramadhan jatuh pada hari Jum'at tanggal 7 April 1989, Depag, Himpunan Keputusan Menteri Agama, 175-177.

${ }^{42}$ Posisi hilal akhir Sya'ban 1410 H / Selasa tanggal 27 Maret 1990 M untuk seluruh wilayah Indonesia berada di atas ufuk sekitar $3 \mathrm{~s} / \mathrm{d} 7$ oleh karenanya baik hilal terlihat atau tidak maka tanggal 1 ramadhan $1410 \mathrm{H}$ jatuh pada hari Rabu tangga 28 Maret 1990 M. Lihat Depag, Himpunan Keputusan Menteri Agama, 180.

${ }^{43}$ Munas Alim Ulama NU di Cilacap pada Nopember 1987 ini sebenarnya, mengukuhkan hasil Munas Alim Ulama NU di Situbondo tahun 1983 yang menegaskan bahwa penetapan Pemerintah tentang awal RSD dengan menggunakan hisab tidak wajib diikuti, lihat Aziz Masyuhuri, Masalah Keagmaan Hasil Muktamar dan Munas Ulama NU ke satu 1926 s/d kedua puluh sembilan 1994, (Surabaya: PP RMI dan Dinamika Press, 1997), 300-301, 325-327.

${ }^{44}$ Lajnah Falakiyah PB NU, Pedoman Rukyat dan Hisab Nahdlatul Ulama, (Jakarta: Lajnah Falakiyah PB NU, 2006), 14. 
ibadah mempunyai nilai ibadah. Oleh karena itu penyelenggaraan rukyatulhilal harus tetap dilaksanakan sekalipun posisi hilal masih di bawah ufuk atau belum imkanurrukyat. ${ }^{45} \mathrm{Hal}$ ini agar keputusan istikmâl yang ditetapkan oleh Nahdlatul Ulama tetap didasarkan pada rukyat, yakni rukyat yang tidak berhasil bukan didasarkan pada perhitungan hisab.

Penetapan awal Ramadan, Syawal, dan Zulhijjah dilakukan oleh Pemerintah (Ithbat al-Hâkim), dengan didasarkan pada hasil rukyat atau istikmâl. Apabila Pemerintah menolak untuk melakukan isbat atau istikmâl maka hasil rukyat itu harus diinformasikan oleh PB NU ke seluruh wilayah melalui jaringan organisasi NU di seluruh Indonesia. ${ }^{46}$ Kewajiban mentaati Pemerintah didasarkan pada Kaidah hukm alhâkim ilzâmun wa yarfa 'al-khilâf, keputusan Pemerintah mengikat dan mengakhiri perselisihan. Kaidah ini menjadi landasan keluarnya fatwa MUI nomor 2 Tahun 2004 tentang Penetapan Awal Ramadan, Syawal, dan Zulhijjah bahwa: 1) Penetapan awal Ramadan, Syawal, dan Zulhijjah dilakukan berdasarkan rukyat dan hisab oleh Pemerintah RI cq Menteri Agama dan berlaku secara Nasional. 2) Seluruh umat Islam di Indonesia wajib menaati ketetapan Pemerintah RI tentang penetapan awal bulan Ramadan, Syawal, dan Zulhijjah tidak berlaku dalam kasus ini. Ketaatan kepada Pemerintah terkait dengan penetapan puasa dan hari raya dilakukan oleh NU dengan catatan, yakni manakala penetapan itu dilakukan berdasarkan keberhasilan rukyat bukan hisab.

Ketetapan Pemerintah tentang puasa dan hari raya yang didasarkan pada kemungkinan hilal dapat dilihat atau hisab imkân alru'yat tidak dapat diterima oleh Nahdlatul Ulama. Imkân al-ru'yat bagi Nahdlatul Ulama bukan solusi untuk mengatasi perbedaan, mengingat ada beberapa versi imkân al-ru'yat, yaitu versi MABIMS, versi organisasi PERSIS, versi ahli astronomi LAPAN, dan versi jamaah tarekat. Namun imkanurrukyat mana yang dipilih? Kata Kyai Ghazalie. Selain itu yang paling prinsipil, kriteria imkân al-ru'yat itu bukanlah rukyat tetapi hisab. Sementara itu penetapan awal bulan kamariah menurut NU harus berdasarkan pada rukyat bukan hisab, tegasnya. ${ }^{47}$

\footnotetext{
${ }^{45}$ Lajnah Falakiyah PB NU, Pedoman Rukyat dan Hisab Nahdlatul Ulama, v

${ }^{46}$ Lajnah Falakiyah PB NU, Pedoman Rukyat dan Hisab Nahdlatul Ulama, $14-15$

${ }^{47}$ A. Khoirul Anam, “KH Ghazalie Masroeri: Imkanur rukyat Bukan Solusi”, http://www.nu.or.id/a,public-m,dinamic-s,detail-ids,44-id, 47305-lang,id-c,nasional-
} 
Rukyat yang dijadikan dasar oleh NU tidak lagi rukyat an sich tetapi sudah dipadukan dengan kriteria lain yaitu imkân al-ru'yat. Hasil rukyat hanya dapat ditolak dengan syarat 1) jika ahli hisab dengan dasar-dasar yang qoth'i (pasti) sepakat akan tidak adanya imkân alru'yat (hilal dapat dirukyat), 2) jika jumlah ahli hisab mencapai batas mutawatir. ${ }^{48}$ Pergeseran ru'yat al-hilal bi al-fi'li ke imkân al-ru'yat dengan tetap mengutamakan rukyat inilah yang sebenarnya telah menyumbangkan adanya perbedaan dalam penetapan hari raya. Hal ini dapat dilihat pada tabel 1 tentang penetapan Idul Fitri pada tahun 1998, 2002, 2006, 2007, dan 2011 di atas. Apabila NU masih menggunakan dasar rukyat tanpa batasan tertentu semestinya perbedaan hari raya idul fitri pada tahun-tahun itu tidak akan terjadi, karena rukyat yang dilakukan pada tahun-tahun itu dilaporkan berhasil.

Mengingat dalam beberapa kasus NU, Muhammadiyah dan Pemerintah terkadang berbeda dalam penetapan puasa dan hari raya bahkan masing-masing berpegang teguh dengan keyakinannya masingmasing maka menarik untuk disimak pandangan dari tokoh Muhammadiyah dan NU. Amien Rais (ketua PP Muhammadiyah saat itu) mengajak agar hubungan hisab rukyat lebih bersifat independen dan berjalan sesuai dengan keyakinannya masing-masing "lakum ru'yatukum wa lî hisâbî." Pendapat ini didukung oleh Masdar F. Mas'udi dari PB NU, bahwa setiap individu memiliki keyakinan dan tidak mudah dipaksakan termasuk dalam hal hisab rukyat, Muhammadiyah dan NU tidak mungkin asal-asalan dalam menentukan hari raya, sebab mengandung unsur ibadah dan shar $i{ }^{4}{ }^{49}$

\section{Penutup}

Wacana hisab rukyat saat ini bukan hanya terbatas pada justifikasi benar salah, tepat atau tidak tepat tetapi lebih pada "ego" masing-masing ormas dalam mempertahankan keyakinannya dan identitas politiknya. Selain itu, Pemerintah juga ikut memberikan kontribusi dalam kisruh penetapan puasa dan hari raya ini. Keputusan Pemerintah seringkali dianggap lebih memihak pada afiliasi ormas dari Menteri Agama yang berkuasa saat itu, sehingga keputusan yang diambil dipastikan akan diabaikan oleh ormas yang menjadi "oposisi".

t,KH+ Ghazalie+Masroeri++Imkanurrukyat+Bukan+Solusi-.phpx (diakses pada 23 Mei 2015).

${ }^{48}$ Lajnah Falakiyah PB NU, Pedoman Rukyat dan Hisab NahdlatulUlama, 39.

${ }^{49}$ Susiknan Azhari, Penggunaan Hisab Rukyat,100. 
Maskufa

Meskipun demikian, sebenarnya perbedaan yang terjadi lebih disebabkan oleh posisi bulan yang berada pada angka kritis, yakni di bawah angka kemungkinan hilal dapat dilihat dua derajat. 